NBER WORKING PAPER SERIES

SINGLE PARENTHOOD AND CHILDHOOD OUTCOMES
IN THE MID-NINETEENTH CENTURY URBAN SOUTH

\author{
Howard Bodenhorn \\ Working Paper 12056 \\ http://www.nber.org/papers/w12056 \\ NATIONAL BUREAU OF ECONOMIC RESEARCH \\ 1050 Massachusetts Avenue \\ Cambridge, MA 02138 \\ February 2006
}

Susan Averett, Bob Margo, Carolyn Moehling, John Murray, Greg Price and participants at the Cliometric Society session at the 2006 ASSA annual meetings offered valuable comments. I thank the National Science Foundation (SES-0109165) and the Earhart Foundation for financial support. Pam Bodenhorn and Veronica Hart provided valuable research assistance. The views expressed herein are those of the author(s) and do not necessarily reflect the views of the National Bureau of Economic Research.

(C2006 by Howard Bodenhorn. All rights reserved. Short sections of text, not to exceed two paragraphs, may be quoted without explicit permission provided that full credit, including $\odot$ notice, is given to the source. 
Single Parenthood and Childhood Outcomes in the Mid-Nineteenth Century Urban South Howard Bodenhorn

NBER Working Paper No. 12056

February 2006

JEL No. I2, J1, N3

\begin{abstract}
$\underline{\text { ABSTRACT }}$
Families are the core social institution and a growing body of research documents the costs of single parenthood for children in the twentieth century. This study documents racial differences in the incidence and costs of single parenthood in the mid-nineteenth century. Data from the urban South reveal two notable consequences of single parenthood. First, white children residing with single mothers left school earlier than children residing with two parents. Black children in single mother homes started school later and left school earlier. Single motherhood is therefore associated with less lifetime schooling for both races, but the consequences of living in a nontraditional home was larger for blacks. Second, single motherhood was associated with an increased incidence of labor force participation for white youth, but not for blacks. Single parenthood imposed costs, in terms of foregone human capital formation, on children in the mid-nineteenth century, but the consequences of single motherhood were mitigated by social norms toward childhood education.

Howard Bodenhorn

Department of Economics

110 Williams Simon Center

Lafayette College

Easton, PA 18042-1776

and NBER

bodenhoh@lafayette.edu
\end{abstract}




\section{Single Parenthood and Childhood Outcomes in the \\ Mid-Nineteenth Century Urban South}

\section{Introduction}

Families are the core social institution and an increasing volume of research documents the rising incidence of single parenthood and its consequences for children (Bobo 2003). Issues surrounding the consequences of single motherhood have special salience for black Americans. According to Fields (2003) about $16 \%$ of white, compared to $48 \%$ of black, children live with a single mother. And the economic costs to children raised in single-mother households are substantial. More than half of single mother households live under the official poverty line and three-fifths receive some form of public assistance. Moreover, children raised in mother-only households have lower academic achievement, are more likely to drop out of school, to become single parents themselves, to have lower labor market attachment and, perhaps, a greater propensity toward crime as young adults than children raised in two-parent households (McLanahan and Bumpass 1988; McLanahan and Sandefur 1994, Kammerer 1918/1969). Thus racial differences in family structure have potentially large implications for racial differences in child welfare and individual economic mobility in later life (Moehling 2004).

Similar if less pronounced racial differences in family structure are well documented for the late nineteenth and early twentieth centuries. Du Bois (1909/1970) and Frazier (1939/1951) contend that slavery destroyed the black family and gave birth to its modern dysfunctions, including single motherhood. The controversy surrounding Moynihan's (1965) now infamous report, which repeated Du Bois' and Frazier's mostly unproved assertions, prompted new historical studies, which found 
that in both slavery and freedom most black children lived in traditional two-parent families but free black children were about twice as likely as white children to live in mother-only households (Furstenberg, Hershberg and Modell 1975; Gutman 1975; Gordon and McLanahan 1991; Ruggles 1994). Mathis (1978) and Krech (1982) argue that comparing black households to the nuclear, twoparent, white norm is hegemonic and fails to recognize the cultural distinctiveness of extended kinship networks among blacks. Nevertheless, even Krech notes that adults provide more education and superior employment opportunities for their own children than for nieces, nephews and other less direct kin.

This study documents the incidence of single parenthood in the urban South in the midnineteenth century. Consistent with the findings of other studies of early black households, African American children were about twice as likely as white children to reside in mother-only households. The second, and novel, aspect of this study is that it documents the consequences for children of residing in a household with one or neither parent. Although previous studies, including Gutman (1975), Morgan, et al. (1993) and Ruggles (1994), document differences in household structure between free blacks and whites in the period before general emancipation, they do not investigate how differences in household structure influenced several childhood outcomes, including school attendance and labor market participation.

A new sample of white and African American children drawn from the manuscripts of the 1860 census provides important new insights into the consequences of being raised in a single-parent household. First, children under nine years and teenage youth between 14 and 16 years of age residing in mother-only households were less likely to have attended school than their counterparts living in two-parent households. During the prime school attendance ages ( 9 through 13 years) single 
motherhood had very modest negative effects on school attendance for either race. Black children were less likely than whites to attend school during these years, but their low attendance rates were more a function of their race than the parental structure of their households. Single motherhood, then, influenced educational attainment because children living in mother-only houses started school later and quit school earlier than children and youth from two-parent households. Second, single motherhood was associated with an increased likelihood that white, but not black, youth between the ages of 14 and 16 participated in the labor force in some capacity. As modern studies attest, the consequences of single motherhood on social and economic mobility are potentially large, and were so in the mid-nineteenth century as well. Only longitudinal data can fully capture the lifetime consequences of growing up in a single-parent household, but cross-sectional data from the midnineteenth century do not provide much reason for believing that the consequences of single motherhood were less profound then than now.

\section{The Historical Incidence of Single Parenthood and Its Consequences for Children}

A multitude of studies have documented the increasing incidence of single motherhood in the US during the past half century. In 1940 about 5 percent of white and 15 percent of black households were headed by single mothers. During the subsequent half-century the incidence of single motherhood tripled for black and white households so that by the mid-1980s nearly half of all black households were headed by a single mother and about 61 percent of black children did not live with two biological parents (Garfinkel and McLanahan 1986; Ellwood and Crane 1990). This section provides a brief discussion of persistent historical racial differences in single motherhood and its likely causes. As Morgan, et al. (1993) note, the historical evidence reminds us that racial differences 
in family structures are not new. Indeed, differences in household structures are seemingly rooted in long-standing differences in family formation processes, many of which are inherited from the past. The social, economic and cultural history of African Americans differs from that of whites and it is not surprising that these differences are reflected in household structures.

Tocqueville (2000, p. 304) may not have been the first to argue that slavery destroyed the black family, but his was an influential early statement of the hypothesis and became the conventional wisdom for generations of historians and sociologists (Du Bois 1909/1970; Frazier 1951). Even as the common wisdom among historians was gradually evolving (Jordan 1968; Blassingame 1979), the cliometric revolution overturned it. Fogel and Engerman (1974) argued that slaveholders faced numerous incentives to encourage stable, two-parent families. For a sample of slave plantations, Gutman $(1976,1987)$ reports two distinct patterns among slave families. One was the traditional male-headed, two-parent household. The other was single-mother households that were typically not the result of being broken due to the death or sale of a once-resident husband and father. An adult male had never resided in these households and Gutman can offer no reason for why slaveholders would devise such a dichotomous system. He concludes that the household structures were chosen by slaves, not imposed by slaveholders. Crawford (1992) reconstructs patterns of the slave family from the WPA slave narrative project and also finds evidence of dual family structures. About two thirds of slave children were raised by or had regular contact with both biological parents. The other third were raised in predominantly single mother households. Sale disrupted slave marriages, but it does not follow that the disruption or the threat of disruption diminished black appreciation for the virtues of two-parent, nuclear households (Gutman 1975).

How did family structures established in slavery translate when African Americans achieved 
their freedom during the antebellum era? The few extant studies of the free black families in the period before general emancipation show that African Americans overwhelmingly adopted the traditional, nuclear, two-parent structure. Gutman (1975), relying on a small sample of free blacks residing in Buffalo, New York in 1850, finds that about 90 percent of households had an adult male present. It is not clear, however, that Buffalo's small free black population in 1850 was representative of free black communities elsewhere in the United States, especially those in the Old South or Gulf Coast cities.

Furstenberg, et al. (1975) investigate the incidence of single-motherhood in the relatively large free black population in antebellum Philadelphia and find that 22.5 percent of black households were headed by single females. This is nearly twice the rate for households headed by native-born whites and Irish immigrants, and nearly seven times the rate for German immigrants. Using a nationally representative sample drawn from the 1850 IPUMS, Ruggles (1994) estimates that about 53 percent of black children 14 years of age or younger resided with both parents compared to 83 percent of white children. That a host of studies document a relatively constant share (20 to 25 percent) of mother-only black households between 1870 and 1940, suggests a persistence that is unlikely to be explained solely by slavery or its legacy. ${ }^{1}$ Matrifocal households, to use Frazier's term, have been much more common in the black than the white community for about two centuries in both slavery and freedom.

\footnotetext{
${ }^{1}$ Du Bois (1909/1970) reports that 20 percent of black children born in Washington, D.C. between 1879 and 1907 were born to unwed mothers. Gordon and McLanahan (1991) find that in 190087 percent of white children, but only 59 percent of black children lived with both parents. Morgan, et al (1993) find that in 1910 the incidence of black single motherhood was about 1.5 times that of whites. In some cities, however, the incidence among blacks was about four times that of whites. Kammerer (1918) reports that out-of-wedlock births accounted for 2.1 percent of all births among whites, but 22.1 percent among blacks in Washington, D.C. in 1911. Frazier (1951) reports the black illegitimacy rate in the rural South in the 1930s was 15.4 percent, and that in the urban South in 1940, 31.1 percent of black households were headed by a single female.
} 
The question of why single parenthood was more common among blacks than whites goes unresolved. Unlike the modern experience, divorce was rare in the mid-nineteenth century, but simple abandonment may have served the same purpose. Consistent with the modern experience, however, Frazier (1951, pp. 89-95) argues that much black single motherhood was by choice and he advances a prescient version of Becker's (1981) theory of family. Frazier argues that the employment opportunities available to black women, mostly in domestic service, and the low earnings capacity of black men as common laborers encouraged black women to establish mother-only households. The traditional marriage contract - one in which wives keep house and raise the children in return for the husbands' provision of subsistence - was unattractive to many women because the partner complementarities were low.

Other common explanations focus on unbalanced sex ratios and racial differences in early mortality (Furstenberg et al. 1975). ${ }^{2}$ Although Morgan et al. (1991) and Ruggles (1994) find little evidence that excess early mortality among black men can explain racial differentials in single motherhood, the incidence and consequences of racial differences in mortality remain an open question. ${ }^{3}$ Explanations relying on unbalanced sex ratios date to at least Du Bois (1909/1970), who noted a national sex imbalance of 1,013 black women for every 1,000 black men in 1900 . But the national figure disguised sharper imbalances in urban areas. In 14 of the 15 cities with the largest

\footnotetext{
${ }^{2}$ Aassve (2000) also notes a fourth potential cause, namely that generous social welfare benefits induce single motherhood. Given the limited public assistance offered to the poor in early America, including the poorhouse, social assistance is unlikely to have meaningfully contributed to out-of-wedlock childbearing in antebellum America, but it is a question worthy of further study. Nevertheless, evidence from the Baltimore almshouse between 1833 and 1843 shows a rising number of claims by adult black women, but a relatively constant number of claims by black children.

${ }^{3}$ Ferrie (2003) challenges the hypothesis that mortality was high and largely random. arguing that mortality was higher among the poor.
} 
black populations, black women outnumbered black men by an average of 1,180 women to 1,000 men. No comparable disparity was identified in any city for whites.

Sex imbalances continue to be offered as explanations of the modern experience (Wilson 1987, 2003), often in conjunction with Becker's (1981) partner complementarities hypothesis. These explanations are based on data which reveal that marriage rates vary positively with sex ratios and the supply of eligible men who enjoy stable earnings prospects. Willis (1999) and Neal (2001) develop models in which both factors play a role and show that the poorest women will remain childless in equilibrium, but that women in other segments of the income distribution may choose between marriage and single motherhood. For these women, small shocks to the marriage market, either in earnings capacities or in the supply of attractive partners, can lead to substantial differences in the likelihood of becoming single mothers. Evidence presented below is consistent with this interpretation. Sharply unbalanced sex ratios, especially in the prime childbearing years, in the urban antebellum South were associated with high rates of single motherhood, probably by choice.

\section{Data and Methodology}

This section first describes the data source and the basic evidence on the incidence of single parenthood in the mid-nineteenth century urban South. It then offers a brief discussion of the empirical methodology employed in later sections.

\subsection{Data}

The effects of family structure on the incidence of childhood poverty, school attendance and labor market participation are studied using data drawn from the population manuscripts of the 1860 
census for Baltimore, Maryland and New Orleans, Louisiana. (Details concerning the construction of the sample are discussed in an appendix.) The choice of these two cities is driven by two factors. First, this study is part of a larger project considering the economic condition of free blacks living in the antebellum South, so the focus here is on southern cities. Second, by the middle of the nineteenth century every southern state, except Maryland and Louisiana, prohibited the education of free blacks (Woodson 1919/1968). Maryland excluded black children from public education, but allowed them to attend private and parochial schools and academies. ${ }^{4}$ Several charity schools and academies were provided by churches, concerned whites, and by blacks themselves. More well-to-do black families could also send their children to any private academy or tutor willing to accept them. ${ }^{5}$ In antebellum New Orleans, free black children could attend public schools, and there were a number of private and parochial schools and academies that served the city's large black community.

One shortcoming of the 1860 census is that census enumerators only asked whether an individual had received any instruction at any time during the past year, whether at a public school, private academy or tutor. Children and youth whose educations were limited to Sunday school were not to be recorded as having been "at school." Given the question asked by enumerators, there is no way of knowing whether the child attended regularly, intermittently, or even just once and Moehling (2004) and Margo (1990) come to different conclusions regarding the interpretation of a similar

\footnotetext{
${ }^{4}$ For more information on Baltimore's public school system, which commenced in 1829, see Shannon (1964) and Sheller (1982).

${ }^{5}$ Advertisements published in Baltimore in the early 1850s suggest that even the middling sorts could afford to send children to private academies. The Academy of Visitation charged $\$ 40$ per annum, payable in quarterly instalments, for elementary education. Children under 10 years could attend for \$20; those between 10 and 12 years paid \$25 (Baltimore American, 3 August 1850). The Baltimore Collegiate Institute for Young Ladies charged $\$ 20$ per annum for elementary education and between $\$ 40$ and $\$ 60$ per annum for more advanced instruction (Baltimore American, 8 September 1851).
} 
question asked in later censuses. A prudent interpretation of responses in the 1860 census is occasional attendance. In 1860 a Maryland legislative committee reported that less than one-half the eligible children attended regularly so that census data likely provide an upper bound estimate to regular school attendance (Shannon 1964). The exclusion of Sunday school instruction, on the other hand, may underestimate black schooling. Although Sunday schools focused on religious instruction, church schools often provided blacks with remedial academic instruction.

One advantage of using the 1860 census in a study of school attendance is that it is possible to control for the effect of household resources. Unlike earlier and later censuses (1870 excepted), the 1860 census collected information on each household's holdings of real and personal estate. Census enumerators in 1860 also collected information on the occupations of household heads as well as the occupations of other household members 15 years and older. Additional information includes the age, sex, literacy, and place of birth of each household member. A household's decision to send a child to school for some part of the academic year depended on a number of factors and, relative to other nineteenth-century censuses, the 1860 census provides a broad panel of controls, most importantly household resources.

Household demand for a child's school attendance was dependent on a number of factors, including the parent's resources and commitment to education. Wealth, literacy, household size, race and immigrant status are all believed to have influenced the decision to send a child to school (Margo 1990). Less information is available about the supply of schooling services, and it is unlikely that every child of a given race in a given city had equal access to school. A series of census ward dummies are included to control for local provision of schools, but it is recognized that dummy variables will not fully capture local differences in availability and accessibility. 
Panel A of Table 1 provides a comparison of family structures for black and white children. Black children were about twice as likely as whites to live in a single-mother or female-headed household. Black children were also about three times as likely to live with neither parent, which was a much more common arrangement among blacks than whites. The incidence of single fatherhood was twice as likely for whites as blacks.

What explains the higher incidence of single motherhood among blacks? The most likely explanation is Du Bois' (1909) contention that sex imbalances in southern cities led to higher rates of single motherhood among black women who simply chose to have children out of wedlock.

Table 2 reports sex ratios for whites and African Americans in Baltimore and New Orleans in 1860. It is readily apparent that in the prime child-bearing years (twenties and thirties) white men outnumbered white women. Among free blacks, however, women outnumbered men by a large margin. For black women entering the marriage market in their twenties the likelihood of finding a mate was low compared to most populations. There were 1,675 free black women for every 1,000 free black men in Orleans Parish, Louisiana and 1,709 free black women for every 1,000 free black men in the city of Baltimore. The sex imbalances were less pronounced for blacks in their thirties, but there were still half again as many free black women as men in this age cohort. If we assume that the African American marriage market transcended legal status, such that marriages between slaves and free blacks were permissible and viable, the sex imbalances become more rather than less pronounced.

The evidence is consistent with theoretical and empirical studies which find that marriage rates vary negatively with the female-male sex ratio and the supply of men with stable earnings prospects (Darity and Myers 1983; Neal 2001). When women have resources or earnings of their 
own to draw on and women outnumber men, there is an equilibrium in which a large segment of the female population favors out-of-wedlock childbearing (Willis 1999).

Panel B of Table 1 reports school attendance rates by age and sex. Racial disparities in school attendance are even more pronounced than differences in household structure. Black children and youth of both sexes attended school at one-fourth to one-half the rate of whites. The age groupings reflect generally accepted mid-nineteenth century educational norms. Vinovskis (1983) reports general resistance to sending children under 9 years of age to school, and little attendance prior to age 6. The "prime" school-age years at mid-century were 9 to 12 or 13 years, after which attendance dropped off dramatically. Most Americans believed that schooling during the formative preadolescent years was beneficial and enough common schools operated in most places to accommodate (white) children in this age group.

The pattern of school attendance for both blacks and whites is consistent with Vinovskis' contention, although attendance rates for 6 to 8 year-olds is too high for there to have been "general" resistance to sending young children to school. Nevertheless, there is a dramatic rise in school attendance among 9 to 13 year-olds. Although school attendance rates by free black children was low relative to whites, finding that 35 to 40 percent of black children in the prime attendance years attended for some part of the year when public facilities were generally unavailable is a testament to the "improving spirit" among these cities' free black inhabitants. Another notable feature is that girls attended school at approximately the same rate as boys, and that feature too transcended race.

Finally, Panel C of Table 1 reports statistics on child labor force participation. Given the tendency of census enumerators in 1860 to underreport occupational information for individuals other than the household head, the reported rates are probably best interpreted as lower bounds and 
reflect regular paid employment rather than intermittent or occasional labor force participation. Although the directions to census enumerators instructed them to record occupations or apprenticeships only for those over 15 years of age, a few enumerators recorded occupations for children as young as 10. Most of the children with listed occupations, however, were 14 to 16 years old. About 5 percent of 14 year-old males, 20 percent of 15 year-olds, and 30 percent of 16 year-old males had recorded occupations. Labor force participation rates among girls were considerably lower than for boys.

\subsection{Empirical Approach}

The empirical strategy adopted here follows Moehling (2004), who extended the method originally developed by Margo (1990). The analysis empirically estimates the effects of three alternative household structures - single motherhood, single fatherhood, and children residing with neither parent - against the alternative of the intact traditional or two-parent household. Unlike some studies of the modern experience, the data do not allow for a consideration of the effects of stepparents or the causes of family disruption on childhood outcomes. ${ }^{6}$

Estimating the effects of family structure is complicated by the fact that family structure itself may be endogenous. The methodological problem is in determining whether differences in outcomes between children living with different kinds of families are causal because the adults establishing alternative household structures may differ in other regards (Ellwood and Jencks 2002). If there is

\footnotetext{
${ }^{6}$ Popenoe (1996), among others, notes that family disruptions due to divorce or voluntary separation have broader and deeper negative effects on child outcomes than disruptions due to death. The evidence concerning stepparents is mixed, but the weight of evidence suggests that stepparents are not a full replacement for biological parents.
} 
something about families that become disrupted or about women who opt to establish single-mother households that would have differentially influenced childhood outcomes regardless of household structure, then the attribution of different outcomes solely to household structure is misleading. Evidence that children raised in dysfunctional families were not much different than children raised in disrupted families would provide support for the contention that unobserved parental characteristics are more important than household structure per se in explaining child achievement (Bumpass and McLanahan 1988). The issue of dysfunction versus disruption deserves further attention but it is well beyond the scope of this study, which follows the literature in accepting that there are some notable consequences to household structure per se.

If unobserved factors that lead to the establishment of a nontraditional household are correlated with factors influencing the choice to enroll a child in school or send him or her into the labor market, failing to account for this endogeneity will lead to biased parameter estimates and the appropriate method is instrumental variable estimation. In the present context, however, it is unclear what such instruments might be. Serious concerns about the effects of endogeneity may be allayed by the results of IV estimation by Manski et al (1992) and McLanahan and Sandefur (1994), which

find that treating household structure as exogenous does not lead to inappropriate inferences. These findings, of course, do not provide a license to ignore the complications arising from potential endogeneity in the present study. But if the potential biases are small and we are careful not to claim too much, treating household structures as exogenous is methodologically acceptable.

\section{Household Structure and School Attendance}

This section estimates the effects of living in a nontraditional household on child and youth 
school attendance. The effects, estimated from probit regressions on the dichotomous school attendance variable, are estimated from the following specification:

$$
(\text { School Attendance })_{\mathrm{jhkw}}=\alpha+\beta \mathrm{S}_{\mathrm{jh}}+\gamma \mathrm{X}_{\mathrm{jh}}+\lambda_{\mathrm{hk}}+\theta_{\mathrm{jw}}+\epsilon_{\mathrm{j}}
$$

where $\mathrm{j}$ indexes the child; $\mathrm{h}$ indexes the household; $\mathrm{k}$ indexes the city; and w indexes the city ward. The vector $\mathrm{S}$ includes dichotomous variables for single mothers, single fathers, and children living with neither parent (the omitted variable is children residing with both parents). The vector $\mathrm{X}$ includes a number of additional individual and family controls, including the child's age, the head of household's age, literacy and nativity; $\lambda$ controls for the city of residence; and $\theta$ controls for the census ward in which the household resided. Separate regressions are estimated for three age cohorts (6-8 years; 9-13 years, and 14-16 years) and two races. Effects are estimated for all children (boys and girls) together. As reported in Table 1, attendance rates by age cohort and race were nearly identical across the sexes and preliminary separate regressions for boys and girls did not yield significantly different coefficients. The final specifications include a dummy variable for boys, but the estimated effect is virtually nil and statistically insignificant for white children. It is small and only sometimes significant for black children.

It is important to estimate household structure effects after controlling for potential household resource effects. It is often suggested that the observed negative outcomes for children raised in nontraditional homes are principally the result of resource constraints faced by single-mother households. Understanding the consequences of single parenthood on child outcomes, then, demands that resource effects are controlled for separately. The baseline specifications include no resource variables and are reported for comparative purposes only. All discussions of the consequences of household structure are drawn only from specifications that include resource 
controls. In addition to household structures, the baseline models include the child's age and its square, a dummy equal to one if the child is male, the number of residents in the household, the number of siblings between 6 and 16 years, and a dummy variable for Baltimore residence. For each age cohort and race, a second set of equations are estimated that add several household resource measures, including whether the household head was literate, his or her age and its square, a dummy variable indicating whether the household owned its own house, and a measure of the household head's occupational status. An alternative specification replaces the home ownership and occupational status variables with total household wealth. A third specification adds a vector of 30 dichotomous variables to capture differential access to schools across 31 city wards.

Given that Tables 3 and 4 report household structure results from 36 separate specifications, the discussion focuses on the estimates provided by the full specifications (Base + Resource + Ward controls). Tables 3 and 4 report the estimated marginal changes (from 0 to 1 ) from probit regressions. Standard errors corrected for nonindependence across households are reported in parentheses. Resource controls in Table 3 are home ownership and occupational status; in Table 4 the resource control is total household wealth.

The results reveal some intriguing patterns in school attendance. Marginal effects reported in Table 3 for white children between 6 and 8 years of age reveal that living with a single mother or single father had a small and insignificant impact on school attendance. For black children, however, living with a single mother reduced attendance by a statistically significant 7 percent. Although the point estimate for the consequence of single fatherhood is larger, it is not significantly different from zero. For the youngest school-age black children, living with neither parent reduced school attendance by 9 percent, relative to young black children residing in a two parent household. The 
estimated marginal impacts reported in Table 4, which include alternative resource controls, are nearly identical to those in Table 3. Young black children living with a single mother or living with neither parent were about 7 to 9 percent less likely than their counterparts living with two parents to attend school.

For children in the mid-nineteenth century's prime school-age years (9 to 13), residing in a household with a single mother had negligible effects on school attendance, a result that holds for both blacks and whites. Blacks, of course, were less likely to attend school at any age, but single parenthood did not compound the negative consequences of race for children in this age group. This finding is consistent with Vinovskis' (1983) observation concerning a powerful social norm that children in the prime attendance years should be sent to school. Although poverty and lesser access limited black school attendance to about half the white rate for 9 to 13 year-olds, an attendance rate of 40 percent represented a remarkable achievement. It is a testament to an "improving" spirit among free blacks and to a broad recognition that long-term economic well being was heavily dependent on education.

Vinoskis documents the popular view that schooling in the teenage years was highly elastic with respect to wealth and social standing and this is readily apparent in the data. Attendance for children in the 14 to 16 age group falls to one-third to one-half the attendance rate of 9 to 13 yearolds. Moreover, single motherhood appears to have been a powerful deterrent to continued attendance at older ages. White youth residing in a single-mother household were about 8 to 9 percent less likely to attend school than youth in two-parent households. For black youth, singlemotherhood reduced school attendance by about 3 to 4 percent, after including resource and ward controls. 
What about the consequences of living with neither parent? Recall that all that is observed in the 1860 census is whether a child resided with neither parent and whether he or she attended school at any time during the previous year. In some instances it was clear that the child was a live-in servant, but it is impossible to assign "foster" status to children not acting as servants. Thus, all children living with neither parent are grouped together, whether they were servants, apprentices, or orphaned or abandoned children taken in by family or friends. Given that resident servants were probably treated in a different fashion than an orphaned niece, this grouping may not capture the nuances of foster care at mid-century. It is, therefore, important not to read too much into the findings, but given the large proportion of children living with neither parent, it is important to understand the upshot of this household structure even if imperfectly.

At every age residing with neither parent was associated with a much lower school attendance rate. Among 6 to 8 year-olds, white children with neither parent attended school at rates 15 percent below those of children in two-parent households. Black attendance rates were about 9 percent lower at these young ages. In the prime school-age years, white attendance rates were 22 percent lower than for children in two-parent households; black attendance rates were 16 percent lower. Finally, white children aged 14 to 16 years living with neither parent attended at rates 31 percent below children in two-parent households. For blacks, the neither-parent effect was less pronounced than for whites at older ages. Black attendance fell by about 6 percent.

Dramatically lower attendance rates among white teens living with neither parent may not be indicative of sharply reduced human capital formation among this group relative to children living with two parents, however. Apprenticeship records from Baltimore reveal that children apprenticed by their fathers were less likely to demand education or schooling covenants in apprenticeship 
indentures (Bodenhorn 2003). Pauper apprentices, on the other hand, were more likely to have such clauses included in the indenture contracts. This suggests that additional human capital formation in the teenage years took the form of skill training after a child had completed his or her primary education. For black children the interpretation is less sanguine. Black children were apprenticed into less lucrative occupations, were less likely to have completed a primary education at the time of the apprenticeship, and Maryland law relieved masters from the responsibility of sending black apprentices to school. Apprenticeship alone does not explain low rates of school attendance among youth in their teens and does not exclude alternative explanations of low relative attendance rates among youth living with neither parent. Moehling's (2004) study suggests that non-kin foster children in 1910 attended at rates about 13 to 20 percent less than children from two-parent families; related foster children attended at rates about 6 to 15 percent less. The results here are broadly consistent with her findings, namely that the long-term costs, in terms of foregone human capital formation, to children of not residing with two parents or, absent that, kin of some type were quite high.

The pattern of results reported in Tables 3 and 4 is consistent with the following interpretation: Single motherhood reduced school attendance among young black children (6 to 8 years) by about 7 to 9 percent, relative to children in two parent households. Being black and living with a single mother also reduced school attendance of children in their mid-teenage years (14 to 16 years), though the effect of single motherhood is less pronounced for these ages than for young children. Single motherhood had negligible effects on school attendance during the prime school age years (9 to 13 years), which attests to the powerful social norm of nearly universal primary education for whites and a less powerful, but still strong, impulse toward educating black children. 
Nevertheless, single motherhood in black households was associated with less lifetime education because black children living with single mothers apparently started school later and left school earlier than children living with two parents. For white children, single motherhood was associated with leaving school early, but it was not associated with reduced attendance at early ages.

It is likely that white teens residing in mother-only households were expected to enter the labor force to provide income for the household (an issue discussed below). ${ }^{7}$ The less pronounced effect of single motherhood on black teens may be due to two effects. First, black teens were much less likely than whites to attend school regardless of household structure so that the result of single motherhood was less pronounced, though a reduction in attendance of 4 percent when the mean attendance rate was only 12 percent seems fairly substantial. Second, given the low wages paid to black workers, the opportunity cost of remaining in school during the mid-teen years may have been lower for blacks than whites. Still, it seems likely that poor single mothers would more often send teens into the labor market to contribute toward the maintenance of the household. The next section investigates the extent of that behavior.

\section{The Effects of Household Structure on Early Labor Force Participation}

Following the practice in Sections 4, this section estimates the effects of living in a nontraditional household on the labor force participation of male teens. As reported in Table 1, only a small fraction of females between 14 and 16 years participated in the labor force, so the focus here

\footnotetext{
${ }^{7}$ It was common for local officers of the court to place children living in mother-only households in apprenticeships when it was believed that the mother was incapable of transforming an adolescent into a productive adult (Bodenhorn 2003). But some apprenticeships were apprenticeships in name only, as children were put out to work in proto-factories or as servants and such children often continued to live at home. It is not clear how much income such apprenticed children would provide to the household, though some did receive modest cash wages.
} 
is on males, about 25 percent of which had sufficient participation in the labor force to merit its acknowledgment by census enumerators. The effects, estimated from probit regressions on the dichotomous labor force participation variable, are estimated from the following specification:

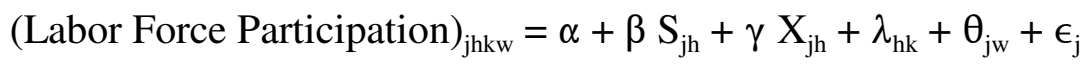

where $\mathrm{j}$ indexes the child; $\mathrm{h}$ the household; $\mathrm{k}$ the city; and $\mathrm{w}$ the city ward. The independent variables are the same as those used in estimating the effects of household structure on school attendance. Three separate specifications are estimated: a baseline model without resource effects; a second model that includes measures of households resources; and a full specification that also includes dummy variables for wards. Finally, separate effects are estimated for black and white youth.

Table 5 reports the results of 12 probit regression specifications. The full specifications for white male youth reveal that living with a single mother increased labor force participation by 11 percent, a result that is robust to alternative measures of household resources. Moreover, the singlemother effect increases in magnitude and statistical significance when controls for household resources and wards are included. For white male youth, living with a single father or with neither parent had no statistically significant effect on labor force participation. Single motherhood was associated with a higher incidence of early labor force attachment among white male youth.

The association between household structure and labor force attachment among blacks differs sharply from the association for whites. Single motherhood had a small and statistically insignificant effect on labor force participation among 14 to 16 year-old black youth. Similarly, single fatherhood had no discernible effect on labor force attachment. Living with neither parent, however, had a meaningful and significant effect on black male youth employment. Black youth living with neither parent were about 16 to 17 percent more likely than black youth living with both parents to have 
regular attachment to the labor force.

While the consequences of family structure differ for blacks and whites, a notable feature is the near equality of labor force participation rates across races. ${ }^{8}$ As is clear from Lines 4 and 5 in Table 5, eliminating the racial differences in youth characteristics leads to small changes in predicted labor force participation. If white youth had the characteristics of black youth, for example, their labor force participation rate would have increased from 23.2 to 25.5 percent when we condition on total household wealth. Giving black youth white characteristics would have increased black participation from 28.1 to 32.2 percent, conditioning on household wealth. If we condition on home ownership and occupational status of the household head, participation rates for both races would have increased from about 5 to 7 percentage points. These findings are consistent with Moehling (2004) who found relatively modest racial effects for male youth employment in 1910 after including a full panel of controls.

An interesting result emerges from the labor force participation regressions, namely that racial differences in participation were driven more by family structure than by race itself. While single motherhood had a large effect on white teen participation, it had no meaningful effect on black youth participation. Living with neither parent, on the other hand, had a meaningful effect on black youth employment, but no effect on white employment. These results then suggest two conclusions. First, while orphaned or abandoned white children were apparently taken into some kind of foster care and not sent out to work at an early age, orphaned or abandoned black children were. Second, just as there was a powerful social norm toward sending 9 to 13 year-olds to school, there was an

\footnotetext{
${ }^{8}$ The test $\mathrm{z}$-statistic for testing the equality of the means is 1.75 (p value $\approx 0.08$ ). Thus, we fail to reject the null hypothesis of equal means at the standard $1 \%$ or $5 \%$ levels.
} 
apparent social norm in the urban South against sending young teens into the labor force. About 40 percent of white 14 to 16 year-olds attended school and another 23 percent had regular labor force attachment, leaving more than one-third of white teens regularly unoccupied. About 60 percent of black youth were apparently unoccupied on a regular basis. A question for future research is accounting for these seemingly unoccupied youth. Some undoubtedly performed household chores. What else did they do with their time?

Evidence from Baltimore's jailhouse records supports the old adage about idle hands and the devil's workshop. Perhaps it is only coincidence that black youth were twice as likely to be idle and to be arrested and sent to jail (Baltimore, 1854-1861). Perhaps it is not. But it is an issue worthy of further study. ${ }^{9}$ If they are connected, the social costs of idleness were considerably higher than they already were by denying black youth equal educational access.

\section{Conclusions}

Just as is the case today, family structure in the nineteenth-century urban South mattered. Family structure was an important determinant of two important childhood outcomes, namely, school attendance and early attachment to the labor force. In the case of school attendance, the consequences of single motherhood were complex and age-dependent. Single motherhood had no meaningful independent effect on school attendance for 9 to 13 year-olds. Among whites, however, single motherhood was associated with lower attendance rates at older ages. For blacks, single motherhood was associated with lower attendance rates for younger children and teens. Living with neither parent

\footnotetext{
${ }^{9}$ In 1858 and 1859 the white arrest rate (5.1 and 4.5 per 1,000 youth) was less than one half the arrest rate of black youth (13.4 and 10.5 per 1,000).
} 
had a uniformly large negative influence on school attendance, an influence that transcended race and age. Finally, single motherhood increased labor force attachment for white male youth. It had little effect on employment rates among black male youth.

Racial differences in household structure, therefore, had important implications for black economic mobility. While single motherhood imposed educational costs on white children and youth, it compounded already large negative racial effects for free blacks. Free blacks were far less likely than whites to attend school due to a host of barriers that interfered with black advancement. At the very moment that the common school movement was taking hold in parts of the urban South, most southern states and municipalities forbade black education. ${ }^{10}$ Maryland and Louisiana were the exceptions. Nevertheless, Maryland excluded free black children from attending white schools and refused to provide any kind of school for black students at the public expense. In the antebellum South, the pretense of separate-but-equal had not yet emerged despite protestations by free blacks that their taxes subsidized white education. ${ }^{11}$ Black education in the antebellum South, when it existed at all, was separate-and-unequal. Thus, the state played a vital role in long-term black poverty and its actions slowed black advancement and imposed large social costs on all racial groups.

\section{Data Appendix}

Sampling Procedure

\footnotetext{
${ }^{10}$ Although Kaestle (1983) contends that the South was laggard in the common school movement, Lachance (2002) finds that per pupil expenditures on public education in New Orleans was higher than in Boston. Shannon (1964) contends that Baltimore's public school system rivaled that of any northern city.

${ }^{11}$ Separate-but-unequal systems emerged in most northern cities, but its emergence in the South came only after the Civil War (Litwack 1961).
} 
The sample used here includes an oversample of free black households. Information on the characteristics of every African American child between 6 and 16 years was collected and recorded. Such information included the child's age, complexion (black or mulatto), place of birth, whether the child had attended school in the past year, and the child's occupation if he or she was employed or serving an apprenticeship. In addition to information on the children, information was also collected on the household head, including age, sex, place of birth, occupation, the value of real and personal estate owned and literacy.

A comparable sample of white children was drawn from the censuses of Baltimore and New Orleans, with an oversample of children of Irish immigrants in Baltimore. The same information was collected and household status was defined and assigned in the same manner. White households were randomly selected to provide a sample of similar size and one that would match the composition by census wards of the African American sample. Thus, if 100 African American households resided in Baltimore's first ward, the sampling procedure was designed to select approximately 100 white households from Baltimore's first ward. The final usable sample contains information on 4,561 African American and 6,133 white children between 6 and 16 years, inclusive. ${ }^{12}$ Given the oversampling of blacks and children of Irish descent, statistics are weighted based on the probability of a household being drawn. STATA's p-weight procedure is used when appropriate. Further, because the sample of children was not independent of household of residence, all reported standard errors are corrected for non-independence using STATA's cluster procedure.

\section{Defining Household Structures}

Classifying children as residing in a female-headed household was trivial. Any child living in a household where the census enumerator recorded the household head as female was so recorded in the data. But because a female head might be a sister, a grandmother, or an unrelated female, an alternative scheme

\footnotetext{
12 The sample also includes an oversample of households headed by Irish immigrants. A second paper will consider the Irish experience in greater detail.
} 
was adopted to separate single mothers from other types of female heads. If the child lived in a household with a female head and had a different surname than any adult in the household, he or she was classified as living with neither parent.

A child was classified as living with a single mother if the female head was related to the child (same surname) and at least 15 and no more than 49 years older than the child. ${ }^{13}$ A child was classified as living with a single father if the male head was not a member of a traditional family, was related to the child and he was at least 15 but no more than 49 years older than the child. A child was classified as living in a twoparent household if first-listed male and first-listed female in the household were related to the child, if the first-listed female was no more than 15 years younger nor more than 20 years older than the first-listed male, and both parents were at least 15 but no more than 49 years older than the child. A child was classified as living with neither parent if his or her surname was different than both parents and all other children in the household. The classification schemes follow those used in coding the IPUMS.

A child was classified as residing in a traditional household, as an alternative the mechanistically defined two-parent household, if the household had all the outward appearances of a traditional family. Such households included a two adults with the same surname followed immediately by one ore more children in descending order of age with the same surname as the married adults. This less precise measure was collected as a robustness check against the two-parent definition. Because the objective and subjective attributions return nearly identical results, we can be reasonably confident that we are indeed identifying two-parent households.

\section{Household Wealth}

Census enumerators were asked to solicit householders' estimates of the dollar value of the

\footnotetext{
${ }^{13}$ This scheme does not and cannot distinguish unmarried aunts from single mothers. It is assumed that the incidence of such households is low.
} 
household's real and personal property. The value of the householder's estate was to exclude liens or the value of rental property. Thus, the reported figures are gross, not net, real estate wealth actually owned by the household. Estimates of personal property were also solicited from householders, and estimates were to encompass the value of all other property, including financial assets, slaves, livestock, jewelry, fixtures, and furniture. The instructions recognized that an accurate valuation might not be had, but marshals were encouraged to obtain as "near and prompt" an estimate as they could. The Census Bureau anticipated the reluctance of many householders to divulge information about their wealth and instructed marshals to cajole and reassure respondents that the information was confidential and would not be handed over to the tax authorities.

It is clear that some marshals were better at cajoling or reassuring householders than others. It was not uncommon for marshals to return a blank (nonresponse) when reporting real and personal estate in the manuscripts. An empty cell in the real estate column is generally taken to represent that the household rented its current habitation, but historians have long debated the meaning of blank cells in the personal property column. Some contend that marshals left the cells blank rather than recording zeroes. Others contend that marshals failed to report small or odd holdings, so that blank cells represent small, but nonzero, values. Conley and Galenson (1998) and Bodenhorn (2003b) review the debate and the data and conclude that marshals had idiosyncratic, nonzero censoring points for personal wealth below which they returned a blank.

Just as there is no consensus on the interpretation of blank cells in the personal estate column, there is no consensus on how to handle the blanks empirically. Conley and Galenson (1998) and Bodenhorn (2003b) employ quantile (median) regression techniques; others estimate Tobit specifications; still others impute a small nonzero value prior to taking the natural logarithm and estimating OLS specifications. Bodenhorn and Ruebeck (2005) estimate the model using the inverse hyperbolic sine specification, which does not require an imputation for zeroes. Some studies, such as Conley and Galenson (1998) found that results and interpretations may not be robust to alternative methods, but Bodenhorn and Ruebeck (2005) find 
their results to be robust to a wide variety of alternative specifications.

This study follows the Bodenhorn and Ruebeck strategy of imputing a ward-specific value for a household not reporting a value for personal estate equal to one-half the smallest value returned by any marshal in a given ward. The inclusion of ward dummy variables then corrects for some of the bias that may be introduced by following this procedure. In addition, robust standard errors are reported. A number of robustness checks were performed and the basic results stand regardless of imputation. This imputation method is chosen because it preserves sample size.

\section{Classification of Occupations}

Two additional types of variables are included to capture potential human capital or household resource effects on child outcomes. One variable (SEI) is a Duncan-style socioeconomic index of occupation prestige (Reiss 1961). The index is based on wages and educational levels associated with several hundred occupations reported in the 1950 census. Translating these values to the 1860 census is straight forward in some instances (e.g., blacksmith, barber, carpenter, bricklayer, minister, etc.), but some occupations listed in the 1860 census were obsolete by 1950 so that assigning them an SEI code required some ingenuity. There were, for example, no carriage drivers in 1950 except for a few in tourist locales. Carriage driving was a reasonably important occupation in 1860 . But there is a modern analog to the carriage driver, namely, the taxi driver. Similarly, modern bus drivers are the analog to stagecoach drivers; and truckers to carters and draymen. When a specific 1860 occupation had no obvious analog to a 1950 employment, a Duncan SEI corresponding to industry (textiles, food, metals, servies, etc.) and broad job classification (laborer, operative, sales, manager, etc.) was assigned.

As an alternative to the SEI codes, all occupations were assigned one of eight industrial classifications: professional, managerial, sales, service, crafts, operatives, laborers, and agriculture. Dummy variables were then constructed for each of these broad occupational classifications. The results are typically 
robust to the continuous and dummy variable measures.

\section{References}

Aassve, Arnstein. 2000. "Economic Resources and Single Motherhood: Incidence and Resolution of Premarital Childbearing among Young American Women.” Max Planck Institute for Demographic Research, Working Paper 2000-015 (December).

Baltimore American, various issues, 1850-1855.

Baltimore City and County Jail. 1854-1861. Proceedings of the Board of Visitors. Maryland State Archives, Annapolis.

Becker, Gary. 1981. A Treatise on the Family. Cambridge, Mass.: Harvard University Press.

Blassingame, John W. 1979. The Slave Community: Plantation Life in the Antebellum South. New York and Oxford: Oxford University Press.

Bobo, Lawrence D. 2003. "Foreword." In Black Fathers in Contemporary American Society: Strengths, Weaknesses, and Strategies for Change. Edited by Obie Clayton, Ronald B. Mincey, and David Blankenhorn. New York: Russell Sage Foundation.

Bodenhorn, Howard. 2003a. "Just and Reasonable Treatment: Racial Differences in the Terms of Pauper Apprenticeship in Antebellum Maryland." NBER working paper w9752 (June).

Bodenhorn, Howard. 2003b. "The Complexion Gap: The Economic Consequences of Color among Free African Americans in the Rural Antebellum South.” Advances in Agricultural Economic History 2, 41-73.

Bodenhorn, Howard and Christopher S. Ruebeck. 2005. "Colorism and African-American Wealth: Evidence from the Nineteenth-Century South.” NBER working paper w11732 (November).

Conley, Timothy G. and David W. Galenson. 1998. "Nativity and Wealth in Mid-Nineteenth-Century Cities.” Journal of Economic History 27:1 (March), 149-165. 
Crawford, Stephen. 1992. "The Slave Family: A View from the Slave Narratives.” In Strategic Factors in Nineteenth Century American Economic History: A Volume to Honor Robert W. Fogel, pp. 331-350. Edited by Claudia Goldin and Hugh Rockoff. Chicago and London: University of Chicago Press.

Darity, William Jr. and Samuel L. Myers, Jr. 1983. "Changes in Black Family Structure: Implications for Welfare Dependency.” American Economic Review 73:2 (May 1983), 59-64.

Du Bois, William E. Burghardt. 1970. The American Negro Family. Cambridge, Mass. and London: MIT Press, 1970. Reprint of 1909 edition.

Ellwood, David T. and Jonathan Crane. 1990. "Family Change among Black Americans: What Do We Know?" Journal of Economic Perspectives 4:4 (Autumn), 65-84.

Ellwood, David T. and Christopher Jencks. 2002. “The Spread of Single-Parent Families in the United States since 1960.” Working paper, Harvard University (October).

Ferrie, Joseph. 2003. "The Rich and the Dead: Socioeconomic Status and Mortality in the United States, 1850-1860. In Health and Labor Force Participation over the Life Cycle: Evidence from the Past, pp. 11-50. Edited by Dora Costa. Chicago and London: University of Chicago Press.

Fields, Jason. 2003. “Children's Living Arrangements and Characteristics: March 2002.” Current Population Reports. U.S. Census Bureau. Study P20-547. Available at http://www.census.gov/prod/2003pubs/p20-547.pdf

Fogel, Robert William and Stanley Engerman. 1974. Time on the Cross: The Economics of American Negro Slavery. New York and London: W. W. Norton \& Co.

Frazier, E. Franklin. 1951. The Negro Family in the United States. Revised and abridged edition. New York: The Dryden Press.

Furstenberg, Frank F. Jr., Theodore Hershberg, and John Modell. 1975. "The Origins of the Female-Headed Black Family: The Impact of the Urban Experience.” Journal of Interdisciplinary History 6:2 (Autumn), 211-33. 
Garfinkel, Irwin and Sara S. McLanahan. 1986. Single Mothers and Their Children: A New American Dilemma. Washington, D.C.: The Urban Institute.

Gordon, Linda and Sara McLanahan. 1991. "Single Parenthood in 1900.” Journal of Family History 16:2, $97-116$.

Gutman, Herbert G. 1975. "Persistent Myths about the Afro-American Family.” Journal of Interdisciplinary History 6:2 (Autumn), 181-210.

Gutman, Herbert G. 1976. The Black Family in Slavery and Freedom, 1750-1925. New York: Vintage Books.

Gutman, Herbert G. 1987. “The Black Family in Slavery and Freedom: A Revised Perspective.” In Power \& Culture: Essays on the American Working Class, pp. 357-379. Edited by Ira Berlin. New York: Pantheon Press.

Jordan, Winthrop D. 1968. White over Black: American Attitudes toward the Negro, 1550-1812. Chapel Hill: University of North Carolina Press, 1968.

Kammerer, Percy Gamble. 1969. The Unmarried Mother: A Study of Five Hundred Cases. Montclair, N.J.: Patterson Smith. Reprint of 1918 edition.

Kaestle, Carl F. 1983. Pillars of the Republic: Common Schools and American Society, 1780-1860. New York: Hill \& Wang.

Krech, Shepard III. 1982. "Black Family Organization in the Nineteenth Century: An Ethnological Perspective.” Journal of Interdisciplinary History 12:3 (Winter), 429-452.

Lachance, Paul. 2002. "Literacy and Provision for Education in Indentures from New Orleans, 1809-1843." Paper presented at McNeill Center Conference (University of Pennsylvania) "Proper and Instructive Education: Children Bound to Labor in Early America" (November).

Litwack, Leon F. 1961. North of Slavery: The Negro in the Free States, 1790-1860. Chicago and London: University of Chicago Press. 
Manski, Charles F., Gary D. Sandefur, Sara McLanahan, and G. Powers. 1992. “Alternative Estimates of the Effect of Family Structure during Adolescence on High School Graduation.” Journal of the American Statistical Association 87, 25-37.

Margo, Robert A. 1990. Race and Schooling in the South, 1880-1950. Chicago: University of Chicago Press.

Mathis, Arthur. 1978. "Contrasting Approaches to the Study of Black Families.” Journal of Marriage and the Family 40:4 (November), 667-676.

McLanahan, Sara and Larry Bumpass. 1988. "Intergenerational Consequences of Family Disruption.” American Journal of Sociology 94:1 (July), 130-52.

McLanahan, Sara and Gary Sandefur. 1994. Growing Up with a Single Parent: What Hurts, What Helps. Cambridge and London: Harvard University Press.

Moehling, Carolyn M. 2004. "Family Structure, School Attendance, and Child Labor in the American South in 1900 and 1910.” Explorations in Economic History 41:1 (month), 73-100.

Morgan, S. Philip, Antonio McDaniel, Andrew T. Miller, and Samuel H. Preston. 1993. "Racial Differences in Household and Family Structure at the Turn of the Century." American Journal of Sociology 98:4 (January), 799-828.

Moynihan, Daniel P. 1965. The Negro Family: The Case for National Action. Washington, D.C.: U.S. Government Printing Office, 1965.

Neal, Derek. 2001. “The Economics of Family Structure.” NBER working paper 8519 (October).

Popenoe, David. 1996. Life without Father: Compelling New Evidence that Fatherhood and Marriage are Indispensable for the Good of Children and Society. New York: Martin Kessler Books.

Reiss, Albert J. 1961. Occupations and Social Status. New York: The Free Press.

Ruggles, Steven. 1994. “The Origins of African-American Family Structures.” American Sociological Review 59:1 (February), 136-151. 
Shannon, William H. 1964. Public Education in Maryland (1825-1868) with Special Emphasis upon the 1860's. Unpublished Ph.D. dissertation, University of Maryland at College Park.

Sheller, Tina H. 1982. "The Origins of Public Education in Baltimore, 1825-1829.” History of Education Quarterly 22:1 (Spring), 23-42.

Tocqueville, Alexis de. Democracy in America. Translated and edited by Harvey C. Mansfield and Delba Winthrop. Chicago and London: University of Chicago Press, 2000.

U.S. Bureau of the Census. Eighth Census (1860). 1864. Population of the United States in 1860. Washington, D.C.: Government Printing Office.

Vinoskis, Maris A. 1983. "Quantification and the Analysis of American Antebellum Education.” Journal of Interdisciplinary History 13:4 (Spring), 761-786.

Willis, Robert J. 1999. “A Theory of Out-of-Wedlock Childbearing.” Journal of Political Economy 107:6 (December), S33-S64.

Wilson, William Julius.1987. The Truly Disadvantaged. Chicago: University of Chicago Press.

Wilson, William Julius. 2003. “The Woes of the Inner-City African American Father.” In Black Fathers in Contemporary American Society: Strengths, Weaknesses, and Strategies for Change, pp. 9-29. Edited by Obie Clayton, Ronald B. Mincy, and David Blankenhorn. New York: Russell Sage Foundation.

Woodson, Carter G. 1919. The Education of the Negro prior to 1861. Washington, D.C.: Associated Publishers, Inc. Reprint edition. New York: Arno Press, 1968. 
Table 1

Family Status of Resident Children and Youth by Race, Baltimore and New Orleans (percent of children 6 to 16 living in household by family status)

\section{A: Household Structures}

Single mother

Female head

Single father

Neither parent

Traditional family

Two-parent family

B: School Attendance during the Past Year

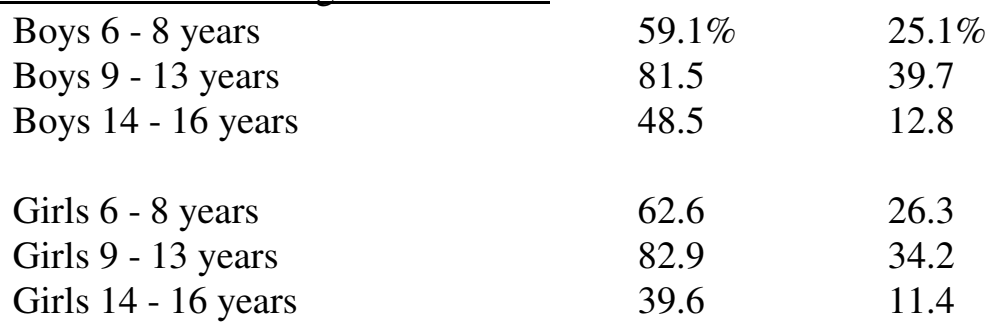

C: Labor Force Participation

$\begin{array}{lcc}\text { Boys } 6-8 \text { years } & 0.0 \% & 0.0 \% \\ \text { Boys } 9 \text { - 13 years } & 0.7 & 1.7 \\ \text { Boys } 14 \text { - } 16 \text { years } & 23.8 & 28.1 \\ & & \\ \text { Girls } 6 \text { - 8 years } & 0.0 & 0.0 \\ \text { Girls } 9 \text { - 13 years } & 0.3 & 1.5 \\ \text { Girls } 14-16 \text { years } & 6.4 & 13.3\end{array}$

Total observations $\quad 6,133 \quad 4,561$

Notes: See appendix for definitions of household structures. All statistics weighted to account for sampling procedures. 
Table 2

Sex Ratios by Race and Age for Baltimore and New Orleans in 1860 (females per 1000 males)

Age group

Baltimore, Maryland

$15-19$

20-29

30-39

40-49

$50-59$

\begin{tabular}{ccl}
\multicolumn{3}{c}{ Baltimore, Maryland } \\
\hline Whites & Free Blacks & All Blacks \\
1,278 & 1,972 & 2,026 \\
1,186 & 1,709 & 1,726 \\
994 & 1,432 & 1,493 \\
983 & 1,241 & 1,305 \\
1,080 & 1,901 & 1,959
\end{tabular}

Age group

New Orleans, Louisiana

$\begin{array}{lcll} & \text { Whites } & \text { Free Blacks } & \text { All Blacks } \\ 15-19 & 1,252 & 1,267 & 1,483 \\ 20-29 & 974 & 1,675 & 1,496 \\ 30-39 & 891 & 1,635 & 1,529 \\ 40-49 & 630 & 1,505 & 1,570 \\ 50-59 & 772 & 1,804 & 1,633\end{array}$

Notes: All Blacks category includes free blacks and slaves.

Source: U.S. Bureau of the Census (1864). 
Table 3

Estimated Effects of Household Structure on School Attendance by Race and Age

Resource Controls include Home Ownership and Occupational Status

(marginal effects from probit regressions)

\begin{tabular}{llll} 
& \multicolumn{3}{c}{ Ages $6-8$} \\
\cline { 2 - 4 } A. White children & Base & Resources & Wards \\
\hline 1. Single mother & & & \\
& -0.03 & -0.02 & 0.00 \\
2. Single father & $(.045)$ & $(.044)$ & $(.047)$ \\
& 0.04 & 0.05 & 0.03 \\
3. Neither parent & $(.048)$ & $(.049)$ & $(.050)$ \\
& -0.16 & -0.15 & -0.14 \\
4. Actual attendance & $(.078) \dagger$ & $(.078) \dagger$ & $(.087)$ \\
5. black characteristics & $57.3 \%$ & $57.3 \%$ & $57.3 \%$ \\
& 57.6 & 52.9 & 50.0 \\
B. Black children & & & \\
1. Single mother & & & \\
& -0.08 & -0.08 & -0.07 \\
2. Single father & $(.034) \dagger$ & $(.034) \dagger$ & $(.036) \dagger$ \\
& -0.07 & -0.07 & -0.09 \\
3. Neither parent & $(.049)$ & $(.050)$ & $(.047)$ \\
& -0.13 & -0.12 & -0.09 \\
4. Actual attendance & $(.035) *$ & $(.036) *$ & $(.039) \dagger$ \\
5. white characteristics & $25.7 \%$ & $25.7 \%$ & $25.7 \%$ \\
& 26.6 & 27.7 & 31.2
\end{tabular}

\begin{tabular}{lll}
\multicolumn{3}{c}{ Ages $9-13$} \\
\hline Base & Resources & Wards \\
-0.05 & -0.04 & -0.02 \\
$(.033) \neq$ & $(.033)$ & $(.032)$ \\
-0.02 & -0.03 & -0.05 \\
$(.038)$ & $(.038)$ & $(.043)$ \\
-0.25 & -0.24 & -0.22 \\
$(.053)^{*}$ & $(.054)^{*}$ & $(.059)^{*}$ \\
$77.5 \%$ & $77.5 \%$ & $77.5 \%$ \\
74.6 & 72.4 & 68.9
\end{tabular}

\begin{tabular}{|c|c|c|}
\hline & Ages $14-16$ & \\
\hline Base & Resources & Wards \\
\hline-0.10 & -0.08 & -0.08 \\
\hline$(.044) \dagger$ & $(.046) \ddagger$ & $(.047) \ddagger$ \\
\hline-0.04 & -0.05 & -0.06 \\
\hline$(.055)$ & $(.058)$ & $(.055)$ \\
\hline-0.30 & -0.28 & -0.31 \\
\hline$(.033)^{*}$ & $(.037)^{*}$ & $(.031)^{*}$ \\
\hline $38.0 \%$ & $38.0 \%$ & $38.0 \%$ \\
\hline 33.6 & 29.2 & 29.4 \\
\hline
\end{tabular}
variables. In addition to household structure, base regressions include child's age and its square, the number of residents in the household, the number of siblings between ages 6 and 16, and a dummy variable equal to one if the child lived in Baltimore. The Resource regressions added to the Base regressions a dummy variable equal to one if the household head was an immigrant, a dummy variable equal to one if the head of the household was literate, the age and its square of the head of the household, a dummy variable equal to one if the family owned their own home (that is, it equals one if the household reported a positive value for real estate wealth), and an occupational status variable or SEI (see the appendix for its construction). The Ward regressions add dummy variables for 30 of the 31 census wards in Baltimore and New Orleans. Robust standard errors corrected for non-independence of households in parentheses. $*$ implies p-value $<0.01 ; \dagger<$ 0.05 ; and $\ddagger<0.10$. 
Table 4

Estimated Effects of Household Structure on School Attendance by Race and Age

Resource Control is Total Household Wealth

(marginal effects from probit regressions)

\begin{tabular}{|c|c|c|c|c|c|c|c|c|c|}
\hline & & ges $6-8$ & & & es $9-13$ & & & Ages $14-1$ & \\
\hline & Base & Resources & Wards & Base & Resources & Wards & Base & Resources & Wards \\
\hline A. White children & & & & & & & & & \\
\hline 1. Single mother & -0.03 & -0.03 & 0.00 & -0.05 & -0.05 & -0.03 & -0.10 & -0.09 & -0.09 \\
\hline & $(.045)$ & $(.045)$ & $(.046)$ & $(.034) \div$ & $(.033) \ddagger$ & $(.032)$ & $(.045) \dagger$ & $(.045) \dagger$ & $(.047) \ddagger$ \\
\hline 2. Single father & 0.04 & 0.05 & 0.03 & -0.02 & -0.02 & -0.04 & -0.04 & -0.05 & -0.06 \\
\hline & $(.048)$ & $(.049)$ & $(.050)$ & $(.038)$ & $(.038)$ & $(.043)$ & $(.055)$ & $(.058)$ & $(.055)$ \\
\hline 3. Neither parent & -0.16 & -0.16 & -0.15 & -0.25 & -0.25 & -0.22 & -0.30 & -0.29 & -0.31 \\
\hline & $(.078) \dagger$ & $(.079) \dagger$ & $(.089) \ddagger$ & $(.054)^{*}$ & $(.054)^{*}$ & $(.059)^{*}$ & $(.033)^{*}$ & $(.037)^{*}$ & $(.030)^{*}$ \\
\hline 4. Actual attendance & $57.3 \%$ & $57.3 \%$ & $57.3 \%$ & $77.5 \%$ & $77.5 \%$ & $77.5 \%$ & $38.0 \%$ & $38.0 \%$ & $38.0 \%$ \\
\hline 5. black characteristics & 57.6 & 57.2 & 54.9 & 74.6 & 72.1 & 69.4 & 33.6 & 28.9 & 27.8 \\
\hline B. Black children & & & & & & & & & \\
\hline 1. Single mother & -0.08 & -0.09 & -0.08 & -0.05 & -0.05 & -0.03 & -0.04 & -0.04 & -0.04 \\
\hline & $(.034) \dagger$ & $(.033)^{*}$ & $(.035) \dagger$ & $(.033)$ & $(.034)$ & $(.036)$ & $(.020) \dagger$ & $(.020) \ddagger$ & $(.019) \ddagger$ \\
\hline 2. Single father & -0.07 & -0.07 & -0.09 & 0.02 & 0.01 & 0.00 & 0.02 & 0.01 & 0.01 \\
\hline & $(.049)$ & $(.050)$ & $(.047)$ & $(.057)$ & $(.056)$ & $(.055)$ & $(.037)$ & $(.035)$ & $(.034)$ \\
\hline 3. Neither parent & -0.13 & -0.13 & -0.09 & -0.19 & -0.18 & -0.16 & -0.07 & -0.06 & -0.06 \\
\hline & $(.035)^{*}$ & $(.036)^{*}$ & $(.039) \dagger$ & $(.037)^{*}$ & $(.038)^{*}$ & $(.039)^{*}$ & $(.021) \dagger$ & $(.021) \dagger$ & $(.019) \dagger$ \\
\hline 4. Actual attendance & $25.7 \%$ & $25.7 \%$ & $25.7 \%$ & $37.1 \%$ & $37.1 \%$ & $37.1 \%$ & $12.0 \%$ & $12.0 \%$ & $12.0 \%$ \\
\hline 5. white characteristics & 26.6 & 29.1 & 32.1 & 38.4 & 43.7 & 50.1 & 11.8 & 20.9 & 21.8 \\
\hline
\end{tabular}

Notes: See appendix for definition of single mother, single father, and neither parent. Table reports estimated marginal effects of change from 0 to 1 for dummy variables. In addition to household structure, base regressions include child's age and its square, the number of residents in the household, the number of siblings between ages 6 and 16, and a dummy variable equal to one if the child lived in Baltimore. The Resource regressions added to the Base regressions a dummy variable equal to one if the household head was an immigrant, a dummy variable equal to one if the head of the household was literate, the age and its square of the head of the household, and the total household wealth. The Ward regressions add dummy variables for 30 of the 31 census wards in Baltimore and New Orleans. Robust standard errors corrected for non-independence of households in parentheses. $*$ implies $\mathrm{p}$-value $<0.01 ; \dagger<0.05$; and $\ddagger<0.10$. 
Table 5

Estimated Effects of Household Structure on Labor Force Participation by Race (marginal effects from probit regressions)

\begin{tabular}{|c|c|c|c|c|c|c|}
\hline \multirow{3}{*}{ A. White youth } & \multicolumn{3}{|c|}{$\begin{array}{c}\text { Resources }= \\
\text { Home Owner and Occupation }\end{array}$} & \multicolumn{3}{|c|}{$\begin{array}{l}\text { Resources }= \\
\text { Total Household Wealth }\end{array}$} \\
\hline & $\overline{\text { Base }}$ & Resources & Wards & Base & Resources & Wards \\
\hline & & & & & & \\
\hline$\overline{1 . \text { Single mother }}$ & $\begin{array}{l}0.10 \\
(.058) \ddagger\end{array}$ & $\begin{array}{l}0.09 \\
(.057) \ddagger\end{array}$ & $\begin{array}{l}0.11 \\
(.078) \dagger\end{array}$ & $\begin{array}{l}0.10 \\
(.058) \ddagger\end{array}$ & $\begin{array}{l}0.09 \\
(.055) \ddagger\end{array}$ & $\begin{array}{l}0.11 \\
(.080) *\end{array}$ \\
\hline 2. Single father & $\begin{array}{l}0.04 \\
(.070)\end{array}$ & $\begin{array}{l}0.03 \\
(.067)\end{array}$ & $\begin{array}{l}0.01 \\
(.061)\end{array}$ & $\begin{array}{l}0.04 \\
(.070)\end{array}$ & $\begin{array}{l}0.04 \\
(.067)\end{array}$ & $\begin{array}{l}0.03 \\
(.067)\end{array}$ \\
\hline 3. Neither parent & $\begin{array}{l}-0.05 \\
(.062)\end{array}$ & $\begin{array}{l}-0.07 \\
(.054)\end{array}$ & $\begin{array}{l}-0.02 \\
(.062)\end{array}$ & $\begin{array}{l}-0.05 \\
(.062)\end{array}$ & $\begin{array}{l}-0.06 \\
(.050)\end{array}$ & $\begin{array}{l}-0.02 \\
(.060)\end{array}$ \\
\hline 4. Actual participation & $23.2 \%$ & $23.2 \%$ & $23.2 \%$ & $23.2 \%$ & $23.2 \%$ & $23.2 \%$ \\
\hline 5. with black characteristics & 21.7 & 31.5 & 30.6 & 21.7 & 24.4 & 25.5 \\
\hline B. Black youth & & & & & & \\
\hline$\overline{1 . \text { Single mother }}$ & $\begin{array}{l}0.04 \\
(.063)\end{array}$ & $\begin{array}{l}0.01 \\
(.064)\end{array}$ & $\begin{array}{l}0.03 \\
(.070)\end{array}$ & $\begin{array}{l}0.04 \\
(.063)\end{array}$ & $\begin{array}{l}0.04 \\
(.064)\end{array}$ & $\begin{array}{l}0.05 \\
(.070)\end{array}$ \\
\hline 2. Single father & $\begin{array}{l}-0.03 \\
(.086)\end{array}$ & $\begin{array}{l}-0.04 \\
(.082)\end{array}$ & $\begin{array}{l}-0.06 \\
(.085)\end{array}$ & $\begin{array}{l}-0.03 \\
(.086)\end{array}$ & $\begin{array}{l}-0.04 \\
(.084)\end{array}$ & $\begin{array}{l}-0.05 \\
(.087)\end{array}$ \\
\hline 3. Neither parent & $\begin{array}{l}0.13 \\
(.083) \ddagger\end{array}$ & $\begin{array}{l}0.11 \\
(.089)\end{array}$ & $\begin{array}{l}0.16 \\
(.096) \ddagger\end{array}$ & $\begin{array}{l}0.13 \\
(.083) \ddagger\end{array}$ & $\begin{array}{l}0.12 \\
(.089)\end{array}$ & $\begin{array}{l}0.17 \\
(.096) \dagger\end{array}$ \\
\hline 4. Actual participation & $28.1 \%$ & $28.1 \%$ & $28.1 \%$ & $28.1 \%$ & $28.1 \%$ & $28.1 \%$ \\
\hline 5. with white characteristics & 30.7 & 26.9 & 33.7 & 30.7 & 28.7 & 32.2 \\
\hline
\end{tabular}

Notes: See appendix for definition of single mother, single father, and neither parent. Table reports estimated marginal effects of change from 0 to 1 for dummy variables. In addition to household structure, base regressions include child's age and its square, the number of residents in the household, the number of siblings between ages 6 and 16, and a dummy variable equal to one if the child lived in Baltimore. The Resource regressions added to the Base regressions a dummy variable equal to one if the household head was an immigrant, a dummy variable equal to one if the head of the household was literate, the age and its square of the head of the household, and either home ownership and occupational status or total household wealth. The Ward regressions add dummy variables for 30 of the 31 census wards in Baltimore and New Orleans. Robust standard errors corrected for non-independence of households in parentheses. * implies p-value $<0.01 ; \dagger<0.05$; and $\ddagger<0.10$. 